Article

\title{
Biological Activity and Antibiofilm Molecular Profile of Citrus aurantium Essential Oil and Its Application in a Food Model
}

\author{
Miroslava Kačániová ${ }^{1,2} \oplus$, Margarita Terentjeva ${ }^{3}{ }^{\oplus}$, Lucia Galovičová ${ }^{1}$, Eva Ivanišová ${ }^{4}$, \\ Jana Štefániková ${ }^{5}{ }^{\circledR}$, Veronika Valková ${ }^{1,5}$, Petra Borotová ${ }^{5}$, \\ Przemysław Łukasz Kowalczewski ${ }^{6}{ }^{\circ}$, Simona Kunová ${ }^{7}$, Soňa Felšöciová ${ }^{8}$, Eva Tvrdá ${ }^{9}$, \\ Jana Žiarovská ${ }^{10}$, Renáta Benda Prokeinová ${ }^{11}$ and Nenad Vukovic ${ }^{12, *}$
}

1 Department of Fruit Science, Viticulture and Enology, Faculty of Horticulture and Landscape Engineering, Slovak University of Agriculture, Tr. A. Hlinku 2, 94976 Nitra, Slovakia;

miroslava.kacaniova@gmail.com (M.K.); l.galovicova95@gmail.com (L.G.); veronika.valkova@uniag.sk (V.V.)

Department of Bioenergetics, Food Analysis and Microbiology, Institute of Food Technology and Nutrition, University of Rzeszow, Cwiklinskiej 1, 35-601 Rzeszow, Poland

3 Institute of Food and Environmental Hygiene, Faculty of Veterinary Medicine, Latvia University of Life Sciences and Technologies, K. Helmanaiela 8, LV-3004 Jelgava, Latvia; margarita.terentjeva@llu.lv

4 Department of Technology and Quality of Plant Products, Faculty of Biotechnology and Food Sciences, Slovak University of Agriculture, Tr. A. Hlinku 2, 94976 Nitra, Slovakia; eva.ivanisova@uniag.sk

5 AgroBioTech Research Centre, Slovak University of Agriculture, Tr. A. Hlinku 2, 94976 Nitra, Slovakia; jana.stefanikova@uniag.sk (J.Š.); petra.borotova@uniag.sk (P.B.)

6 Institute of Food Technology of Plant Origin, Poznań University of Life Sciences, 31 Wojska Polskiego St., 60-624 Poznań, Poland; przemyslaw.kowalczewski@up.poznan.pl

7 Department of Food Hygiene and Safety, Faculty of Biotechnology and Food Sciences, Slovak University of Agriculture, Tr. A. Hlinku 2, 94976 Nitra, Slovakia; simona.kunova@uniag.sk

8 Department of Microbiology, Faculty of Biotechnology and Food Sciences, Slovak University of Agriculture, Tr. A. Hlinku 2, 94976 Nitra, Slovakia; sona.felsociova@uniag.sk

9 Department of Animal Physiology, Faculty of Biotechnology and Food Sciences, Slovak University of Agriculture, Tr. A. Hlinku 2, 94976 Nitra, Slovakia; eva.tvrda@uniag.sk

10 Department of Plant Genetics and Breeding, Faculty of Agrobiology and Food Resources, Slovak University of Agriculture, Tr. A. Hlinku 2, 94976 Nitra, Slovakia; jana.ziarovska@uniag.sk

11 Department of Statistics and Operations Research, Faculty of Economic and Management, Slovak University of Agriculture, Tr. A. Hlinku 2, 94976 Nitra, Slovakia; renataprokein@gmail.com

12 Department of Chemistry, Faculty of Science, University of Kragujevac, P.O. Box 12, 34000 Kragujevac, Serbia

* Correspondence: nvchem@yahoo.com or nvukovic@kg.ac.rs; Tel.: +38-134-336-223; Fax: +38-134-335-040

Academic Editors: Natalizia Miceli and Francesca Mancianti

Received: 26 July 2020; Accepted: 28 August 2020; Published: 30 August 2020

check for

\begin{abstract}
The main aim of the study was to investigate the chemical composition, antioxidant, antimicrobial, and antibiofilm activity of Citrus aurantium essential oil (CAEO). The biofilm profile of Stenotrophonomonas maltophilia and Bacillus subtilis were assessed using the mass spectrometry MALDI-TOF MS Biotyper and the antibiofilm activity of Citrus aurantium (CAEO) was studied on wood and glass surfaces. A semi-quantitative composition using a modified version was applied for the CAEO characterization. The antioxidant activity of CAEO was determined using the DPPH method. The antimicrobial activity was analyzed by disc diffusion for two biofilm producing bacteria, while the vapor phase was used for three penicillia. The antibiofilm activity was observed with the agar microdilution method. The molecular differences of biofilm formation on different days were analyzed, and the genetic similarity was studied with dendrograms constructed from MSP spectra to illustrate the grouping profiles of S. maltophilia and B. subtilis. A differentiated branch was obtained for early growth variants of $S$. maltophilia for planktonic cells and all experimental groups. The time span can be reported for the grouping pattern of B. subtilis preferentially when comparing to the
\end{abstract}


media matrix, but without clear differences among variants. Furthermore, the minimum inhibitory doses of the CAEO were investigated against microscopic fungi. The results showed that CAEO was most active against Penicillium crustosum, in the vapor phase, on bread and carrot in situ.

Keywords: bitter orange essential oil; biological activity; Stenotrophomonas maltophilia; Bacillus subtilis; Penicillinum; glass; wood; food

\section{Introduction}

Citrus aurantium L. (Rutaceae) or bitter orange is not only used in the food industry, but it is also well-known for its application in the treatment of anxiety [1], lung, and prostate cancers [2], gastrointestinal diseases and obesity [3,4]. C. aurantium acts as an appetite suppressant and was prioritized for the replacement of ephedra-containing (Ephedra sinica L.) weight loss products [4-6]. Fruits of C. aurantium are a source of flavonoid-type compounds with diverse biological effects [7-9]. Additionally, the presence of flavonoid glycosides [10], biogenic amines, and flavanones has been reported [11,12]. Previous studies were focused on antimicrobial and health-promoting activities of different parts of C. aurantium, such as fruits and flowers, as well as essential oils obtained thereof [13-15]. Furthermore, substantial research has been focused on the chemical composition of essential oils prepared from various parts of Citrus aurantium growing in Pakistan [16], Brazil [17,18], Morocco [19], Iran [20,21], Croatia [22], northern Tunisia [23], India [24], and Algeria [25,26]. Essential oils of C. aurantium were reported to be a source of bioactive compounds with antimicrobial $[19,21,23,27]$, antioxidant [19,22,23], anti-inflammatory [18], and anti-anxiety properties [20].

The ability of bacteria to adhere to the surface provides them with a range of physiological benefits and advantages for their survival, including biofilm formation [28]. Stenotrophomonas maltophilia is a gram-negative opportunistic nosocomial pathogen $[29,30]$, although its role in the pathogenesis of infection in immunocompromised and hospitalized patients often remains unclear [31,32]. Studies on the virulence factors of $S$. maltophila are scarce [33,34]. S. maltophilia was reported to form biofilms on abiotic surfaces [35-37], with significant differences among clinical isolates of the bacterium. Bacillus subtilis is a gram-positive, spore-forming bacterium that is ubiquitous in the soil and rhizosphere environment. It is a well-recognized biofilm-producer on plant root systems, ensuring the protection of plants against numerous pathogens. Furthermore, the presence of $B$. subtilis biofilms has been linked to plant growth promotion [38,39]. The genus Penicillium are fundamentally saprophytic and ubiquitous fungi, which are characterized as producers of novel bioactive compounds, blockbuster drugs, such as penicillin [40] and the anticholesterolemic agent compactin [41], miscellaneous antitumor products [42], and mycotoxins contaminating food [43].

Natural plant materials have been used as food preservatives against both bacteria and fungi to control organoleptic changes, off-flavors, and mycotoxin production [44-46]. Natural mixtures have been applied to a variety of foodstuff, including bakery products and vegetables; however, few data on the antifungal activity of natural plant material in bread and carrots have been found within a few papers reporting on the use of natural mold in the products $[47,48]$.

The aim of our study was to examine the antioxidant, antimicrobial, and antibiofilm activity of bitter orange essential oil (Citrus aurantium) against biofilm-forming bacteria Stenotrophomonas maltophilia and Bacillus subtilis by evaluating different biofilm-forming stages using MALDI-TOF MS, as well as Penicillium spp. Growth control by contact and the vapor method. 


\section{Results and Discussion}

\subsection{Chemical Composition of Bitter Orange Essential Oil (Citrus aurantium L., CAEO)}

The main volatile compounds of the bitter orange essential oil (Citrus aurantium L.) (CAEO) based on the reduced percentage were linalyl acetate $(63.37 \%), \alpha$-terpineol $(8.84 \%)$, geranyl acetate $(6.02 \%)$ and neryl acetate $(3.77 \%)$ (Table 1$)$. While Bourgou et al. [49] reported that the main volatile components of CAEO were linalool, linalyl acetate, and alpha terpineol, Rahimi et al. [50] detected linalool and $\alpha$-tepineol as well. Sarrou et al. [51] stated that limonene (94.67\%), $\beta$-myrcene $(2.00 \%)$, linalool $(0.67 \%), \beta$-pinene $(0.62 \%)$ and $\alpha$-pinene $(0.53 \%)$ were the main terpenes of the $C$. auratium peel essential oil grown in Greece. Bourgou et al. [49] concluded that differences in the quality and quantity of volatile ether components might be caused by genetic, environmental, geographical, and seasonal factors. In the study of Zarrad et al. [52], limonene (87.523\%), linalool (3.37\%), and $\beta$-myrcene (1.63\%) were the main compounds in C. aurantium fruits of Tunisian origin.

Table 1. Main components of bitter orange essential oil (Citrus aurantium).

\begin{tabular}{ccc}
\hline Name & Synonyms & TIC\% Area \\
\hline sabinene & $4(10)$-thujene & $0.32 \pm 0.06$ \\
3-carene & & $0.47 \pm 0.09$ \\
$\beta$-myrcene & & $2.32 \pm 0.31$ \\
D-limonene & eucalyptol & $1.57 \pm 0.11$ \\
1,8-cineol & ocimene-X & $2.70 \pm 0.28$ \\
cis-ocimene & & $0.88 \pm 0.07$ \\
$\beta$-cis-ocimene & & $2.39 \pm 0.21$ \\
$\alpha$-terpinolene & $0.58 \pm 0.09$ \\
linalyl acetate & p-menth-1-en-8-ol & $63.37 \pm 2.78$ \\
caryophyllene & isobicyclogermacrene, & $0.34 \pm 0.13$ \\
(-)- $\alpha$-terpineol & lepidozene, isolepidozene & $0.33 \pm 0.06$ \\
bicyclogermacrene & Nerol & $3.77 \pm 0.44$ \\
neryl acetate & neryl alcohol & $6.02 \pm 0.52$ \\
geranyl acetate & trans-geraniol & $1.63 \pm 0.07$ \\
cis-geraniol & lemonol geranyl alcohol & $3.68 \pm 0.41$ \\
\hline geraniol & a mean value \pm SE &
\end{tabular}

\subsection{Antioxidant Activity of CAEO}

The DPPH radical inhibition value of C. aurantium essential oil was $13.93 \%$. Khettal et al. [53] found that the antioxidant activity of C. aurantium was $13.34 \%$, while Bendaha et al. [54] reported activity of $15.33 \%$. Choi et al. [55] investigated the radical scavenging activities of 34 citrus essential oils by the DPPH assay, where four essential oils of Citrus aurantium L. showed scavenging effects from $17.7 \%$ to $34.1 \%$.

\subsection{Antimicrobial Assay}

The highest antibacterial activity of CAEO against Stenotrophomonas maltophilia was $17.67 \pm 0.58 \mathrm{~mm}$, less than those for chloramphenicol-33.33 $\pm 1.53 \mathrm{~mm}$. Antimicrobial activity was furthermore observed against Bacillus subtilis $(15.67 \pm 1.53 \mathrm{~mm})$ followed by P. crustosum $(10.67 \pm 1.15 \mathrm{~mm})$, P. expansum $(8.67 \pm 0.58 \mathrm{~mm})$ and $P$. citrinum $(7.33 \pm 1.53 \mathrm{~mm})$. In another study, the EOs extracted from the peel of C. aurantium showed little antimicrobial activity against B. cereus, S. flexneri, K. pneumoniae, and Colletotrichum capsici [56]. Gram-positive bacteria were generally more sensitive to the activity of the CAEO [57]. Previous reports suggest that the antimicrobial activity of CAEO depends on 
specific microbial species; however, the activity is strain-dependent [58-60], which is in agreement with our results.

\subsection{Antibiofilm Activity of CAEO}

The antibiofilm activity (minimal biofilm inhibition concentration, MBIC) values of 50 and 90 were $8.47 \mu \mathrm{L} / \mathrm{mL}$ and. $9.21 \mu \mathrm{L} / \mathrm{mL}$ for S. maltophilia, and $8.56 \mu \mathrm{L} / \mathrm{mL}$ and $9.18 \mu \mathrm{L} / \mathrm{mL}$ for B. subtilis, respectively. According to Fathi et al. [61], MBICs for E. coli and K. pneumoniae to C. aurantium essential oil in the study were $100 \mathrm{mg} / \mathrm{mL}$ and $150 \mathrm{mg} / \mathrm{mL}$, respectively. The antimicrobial activity of CAEO reported by Gniewosz et al. [62] was $1.25 \mathrm{mg} / \mathrm{mL}$ MIC and $5 \mathrm{mg} / \mathrm{mL}$ MBC for S. aureus, $2.5 \mathrm{mg} / \mathrm{mL}$ and $5 \mathrm{mg} / \mathrm{mL}$ in case of Saccharomyces cerevisiae, and $2.5 \mathrm{mg} / \mathrm{mL}$ and $5 \mathrm{mg} / \mathrm{mL} \mathrm{MBC}$ with respect to S. cerevisiae.

\subsection{Studies on Biofilm Development and Molecular Differences on Surfaces after Treatment with C. aurantium EOs}

The developmental stage spectra of S. maltofilia biofilm during the experiment period are shown in Figure 1. The experimental groups were treated with CAEO. The arrangement of spectra in pairs was made by evaluating the growth on different surfaces. Spectra of planktonic cells were obtained from the culture medium.

The agreement of the control planktonic spectrum with the experimental spectrum obtained from wood was observed for three days from the start of the experiment. In contrast, the glass spectrum was significantly different when compared to the planktonic spectrum. Furthermore, on day 5 (Figure 1B), it was observed that two experimental groups were significantly different from the control planktonic cells. In the following days (7-14), differences in the experimental groups compared to the control planktonic spectrum were also noted (Figure $1 \mathrm{C}-\mathrm{F}$ ).

CAEO was added to media containing B. subtilis cell culture. Figure 2 displays the MALDI-TOF spectra at the different stages of the B. subtilis biofilm development from day 3 to 14 of the experiment. Each pair of spectra $(\mathrm{A}-\mathrm{F})$ represents the same day of the biofilm growth. Experimental biofilm samples were taken from glass or wood solid surfaces. Planktonic cells that served as a control sample were obtained from liquid media. The mass spectra of experimental and control samples at days 3-7 (Figure 2A-C) exhibited the similarities. Degradation of the experimental spectra in comparison to the control was detectable following 9-12 days (Figure 2D,E), after which CAEO started to inhibit the growth of B. subtilis biofilm. Spectra from day 14 (Figure 2F) following the CAEO addition showed a complete degradation of bacterial biofilms in the experimental samples. 
A
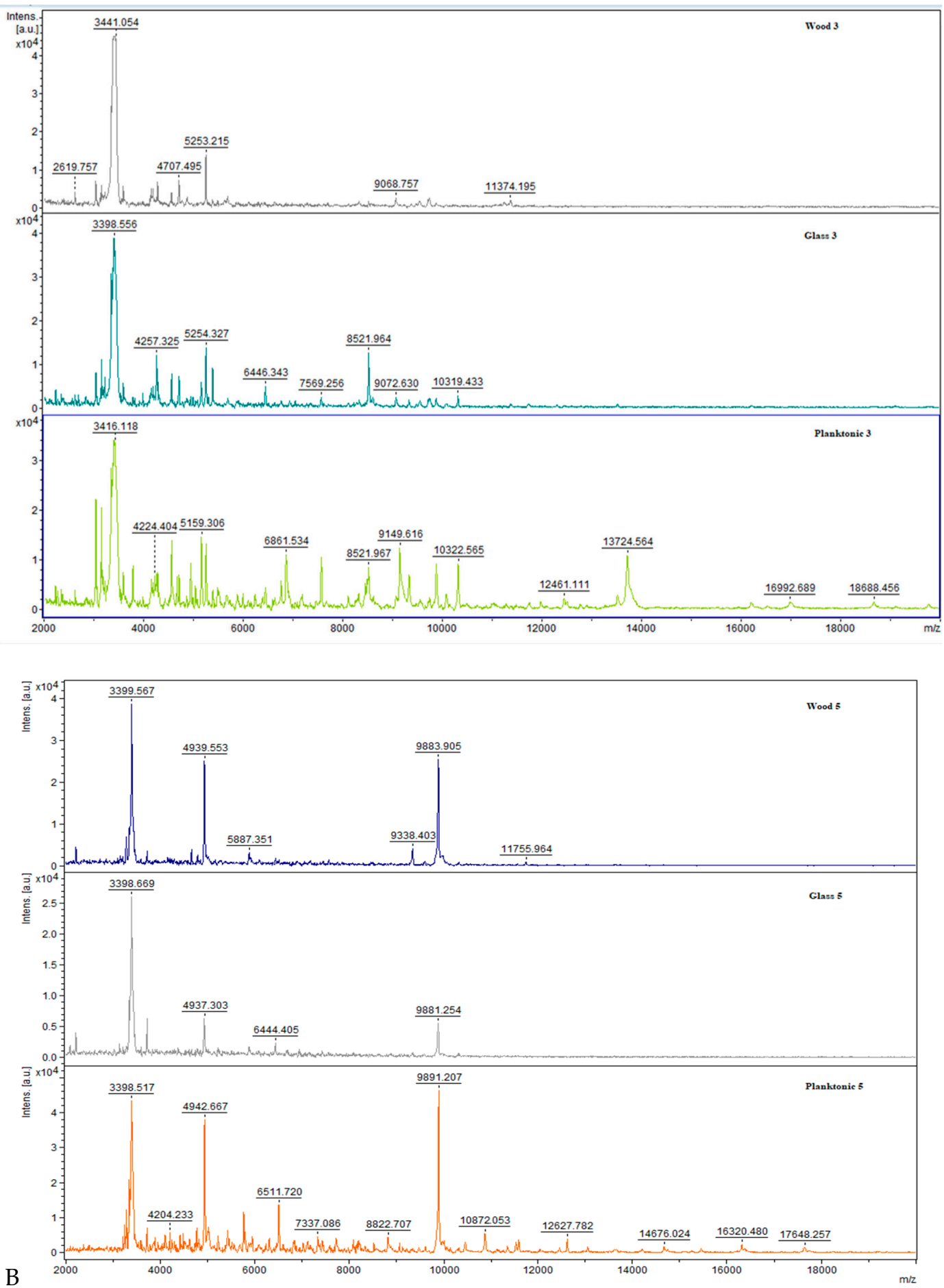

Figure 1. Cont. 

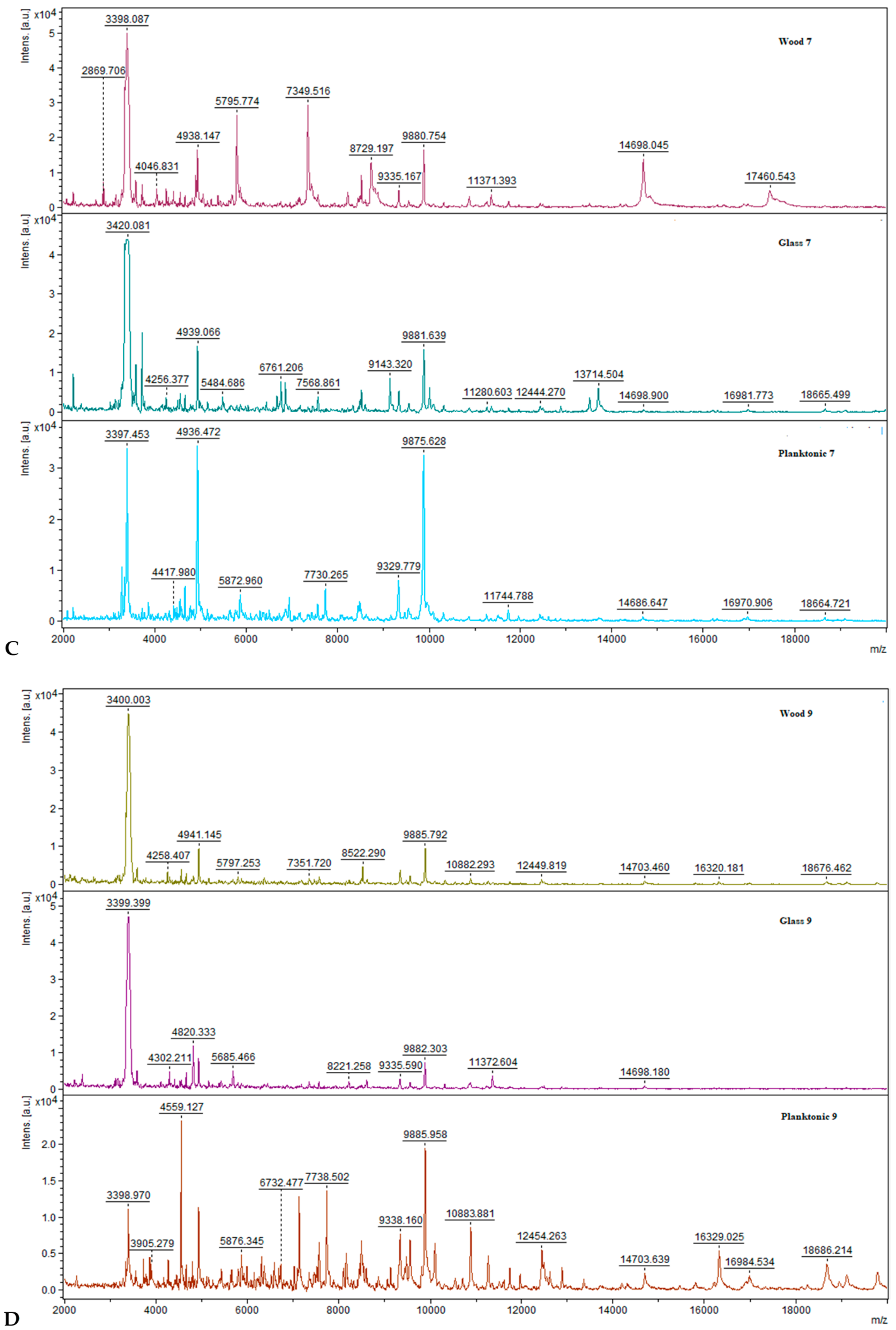

Figure 1. Cont. 

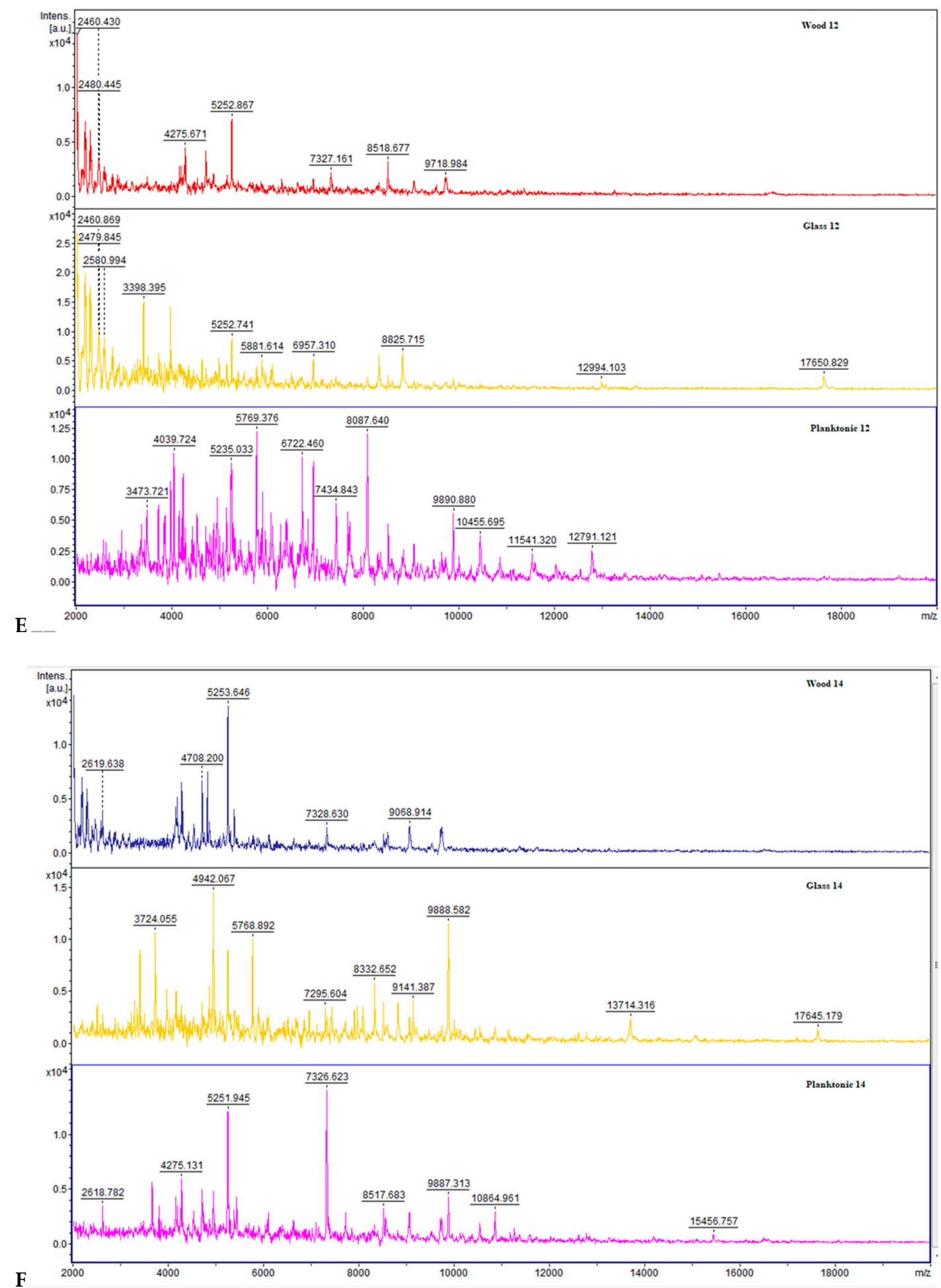

Figure 1. Representative MALDI-TOF mass spectra of S. maltophilia: (A) 3 day, (B) 5 day, (C) 7 day, (D) 9 day, (E) 12 day, (F) 14 day. 

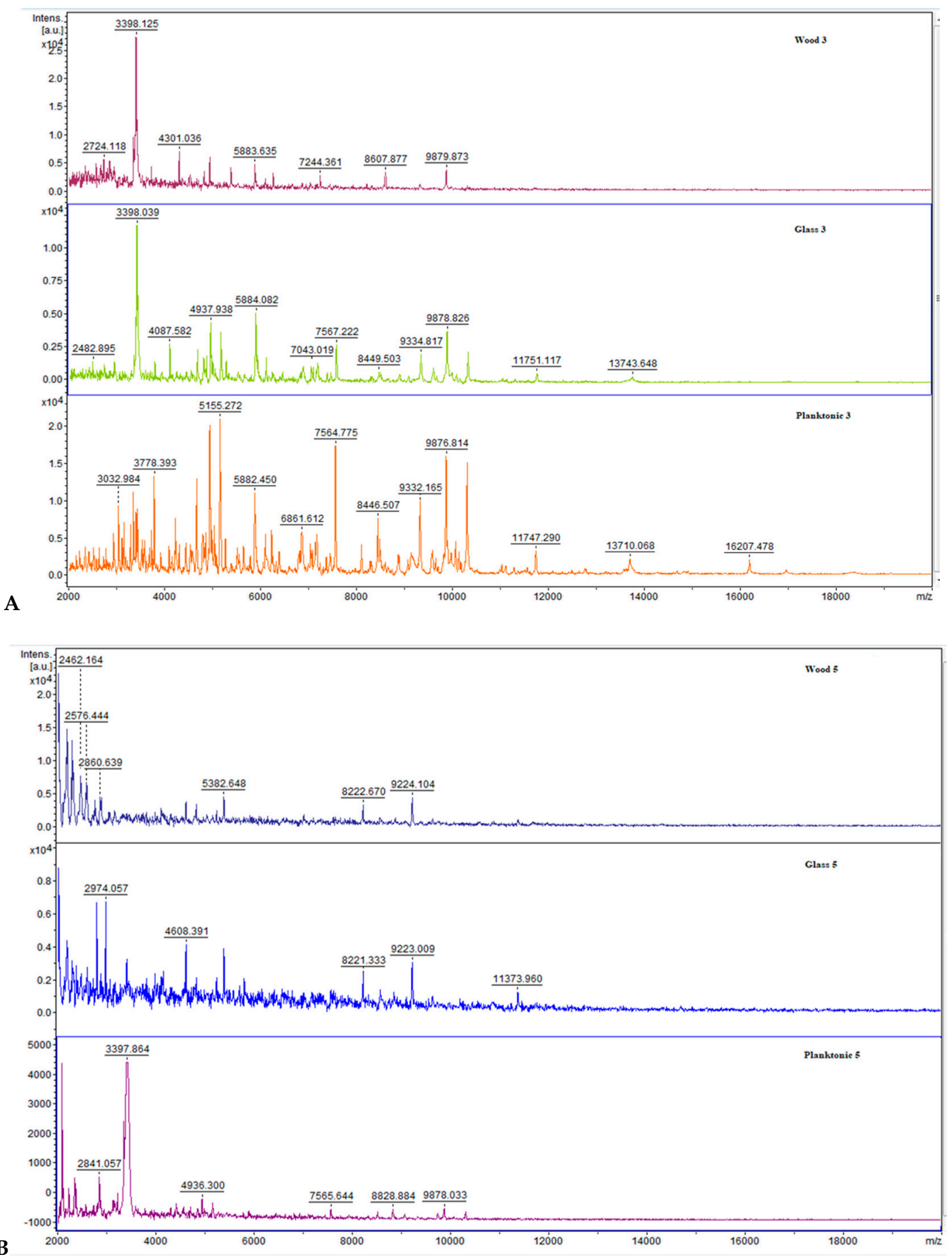

Figure 2. Cont. 

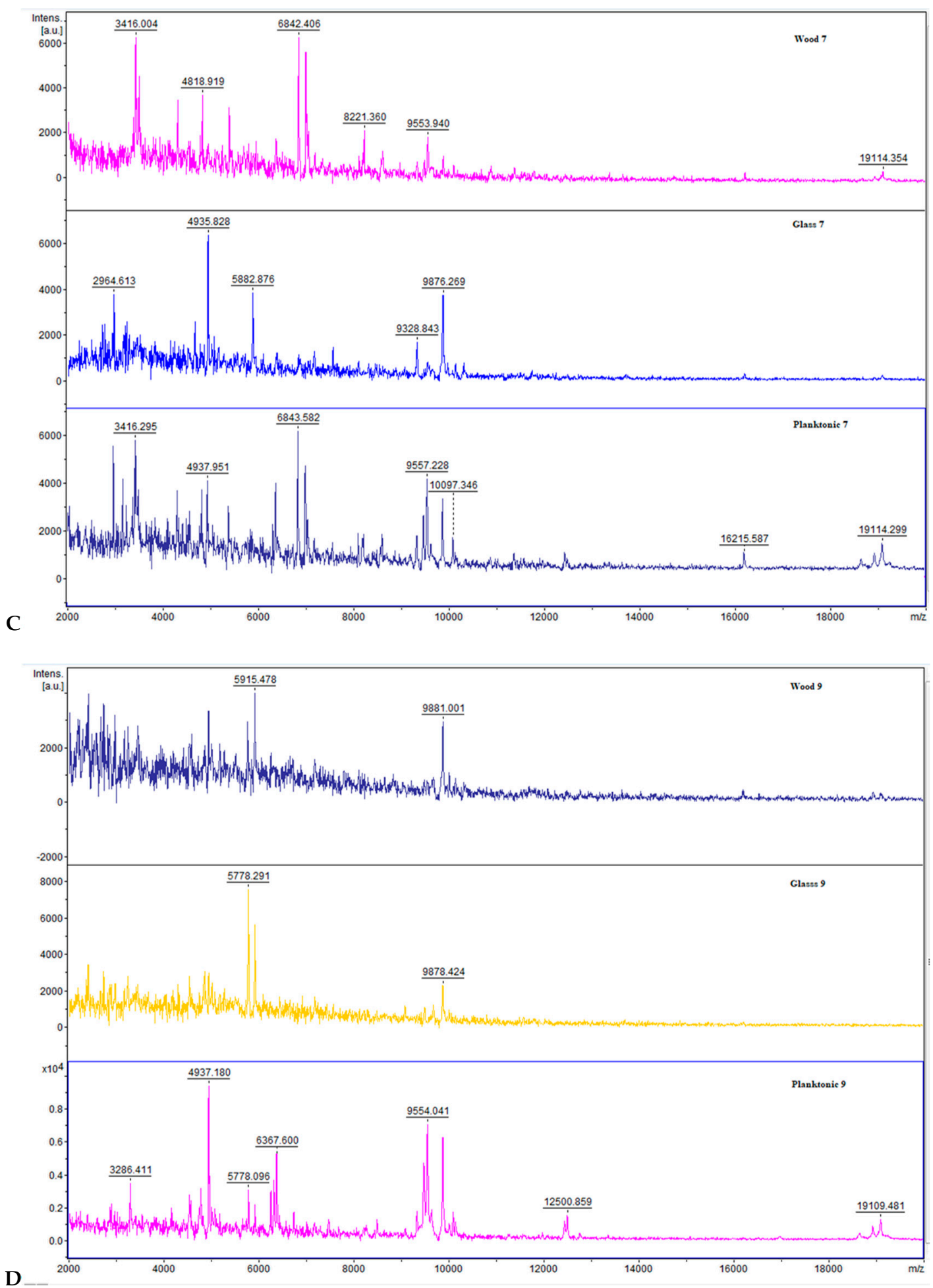

Figure 2. Cont. 

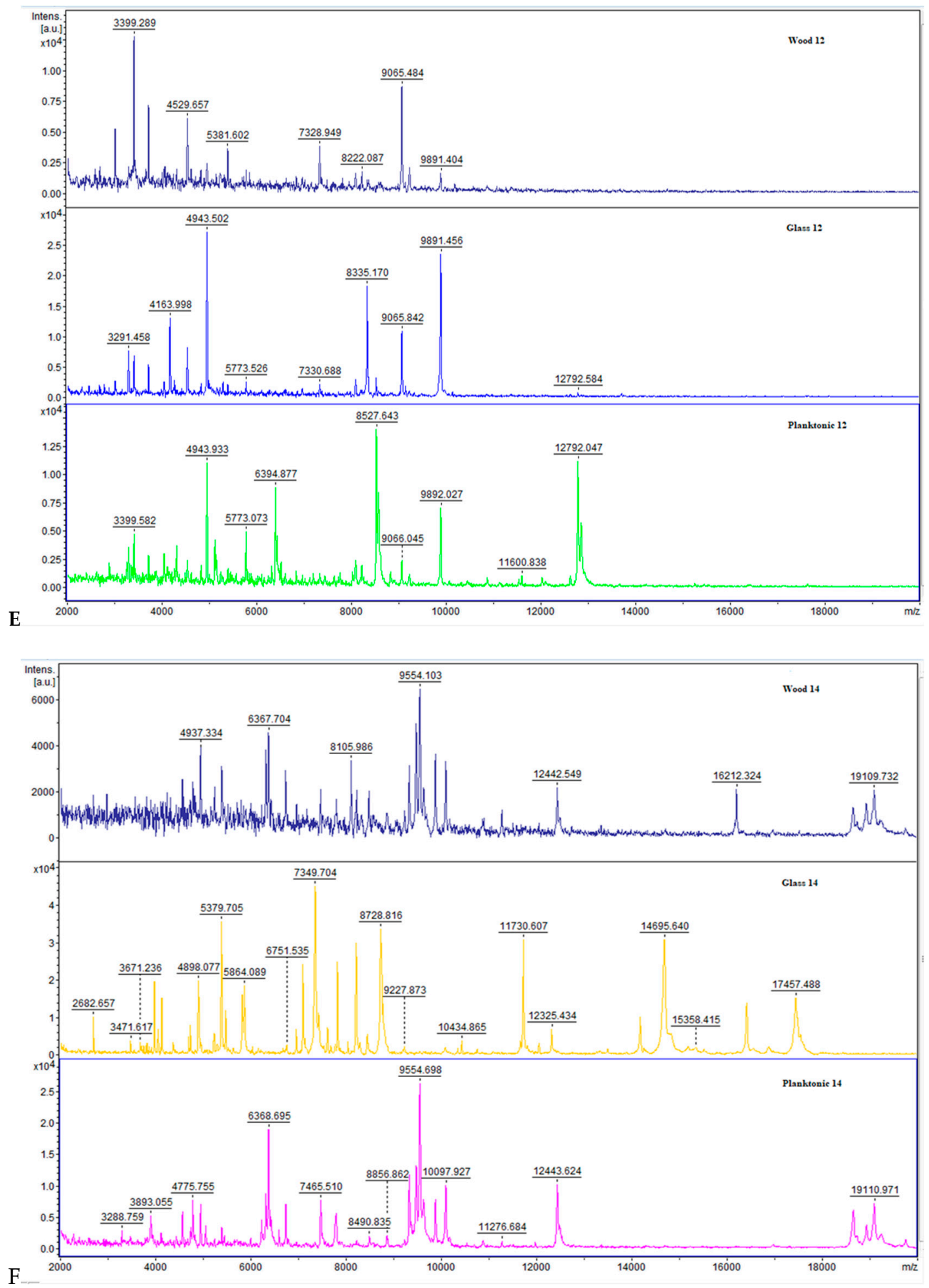

Figure 2. Representative MALDI-TOF mass spectra of B. subtilis: (A) 3 day, (B) 5 day, (C) 7 day, (D) 9 day, (E) 12 day, (F) 14 day. 
Altogether, we observed three main clusters divided into five subclusters on the dendrogram of S. maltophilia from the experimental group treated with CAEOs (Figure 3). The highest similarity of SMEs was recorded for the experimental group on day 3 with planktonic cells. All control groups except for those from day 14 were included in the same cluster. In the second cluster, experimental groups from day 5 were included. Experimental groups of days 5 and 7 showed larger MSP distances than groups of other days. The differentiation of these experimental groups into a separate cluster was induced by a change in the structure of the biofilm, due to the CAOE.

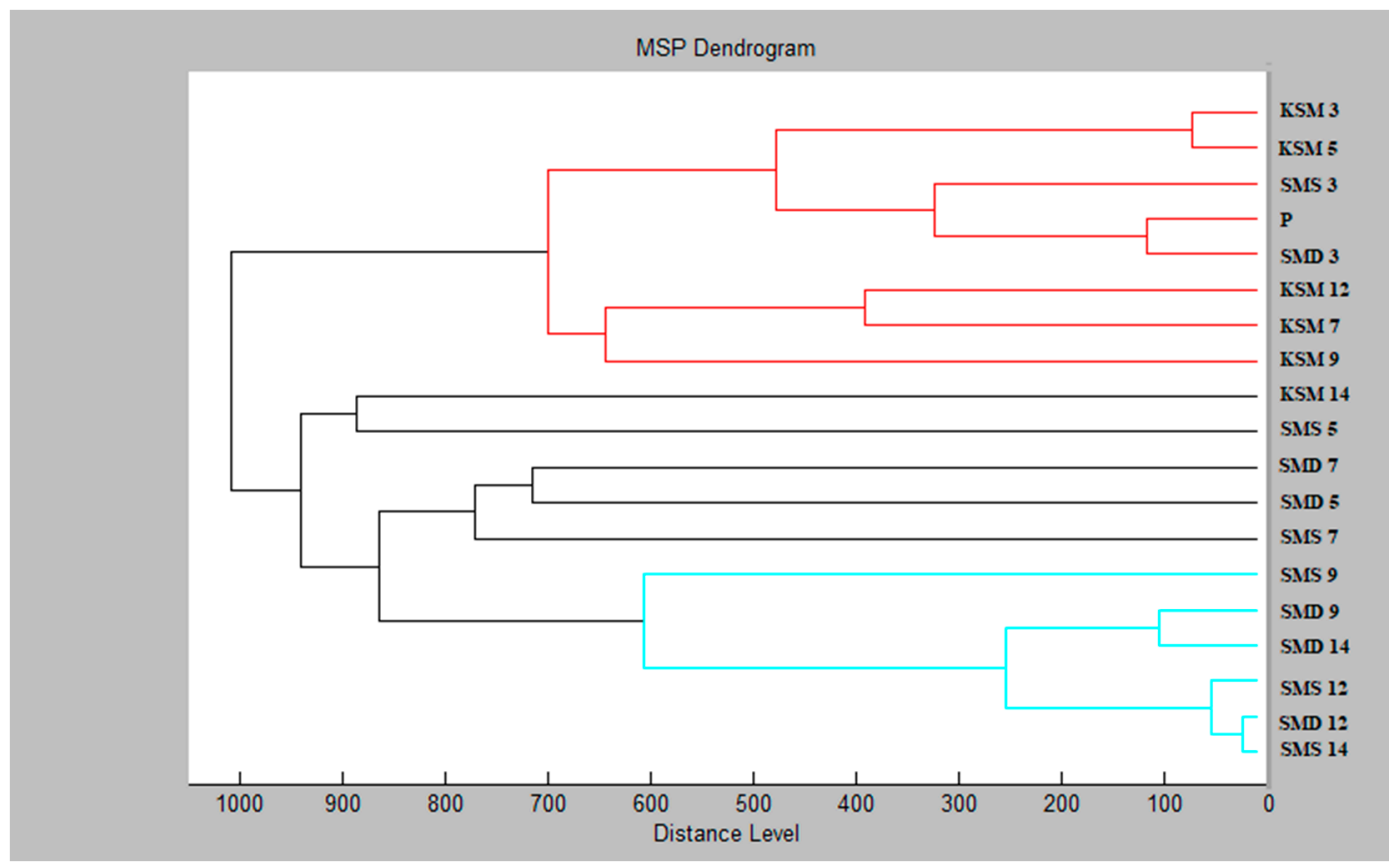

Figure 3. Dendrogram of S. maltophilia with MSP for planktonic cells and all experimental groups. Sample name abbreviations: K-control; SM-Stenotrophomonas maltophilia; S-glass; D-wood; P-planktonic cells.

The B. subtilis dendrogram consists of two main clusters with a high degree of similarity recorded primarily on days 3 to 7 . The constructed dendrogram (Figure 4) shows the same manner of grouping as in the case of the mass spectra, the similarity of the experimental group up to 7 days with the shortest MSP distances. In other samples, relatively different spectra were detected. Planktonic spectrum and control groups up to day 9 were included in the same main cluster. The second cluster contains separate experimental groups for days 12 and 14 in a separate branch.

MALDI-TOF MS Biotyper has been proved to be an effective method for microbial identification and biofilm development evaluation [63]. MALDI-TOF was able to detect the surface characteristics on which bacteria were grown and differentiate $S$. maltophilia biofilm development on plastic and glass surfaces. The authors found that the bacteria matured more rapidly on plastic surfaces and reached the dispersed stage in a shorter time. S. maltophilia attached to polystyrene within $2 \mathrm{~h}$ of incubation, and the biofilm formation increased over time, reaching the maximum growth at $24 \mathrm{~h} \mathrm{[63].} \mathrm{A} \mathrm{different} \mathrm{capacity}$ of biofilm-production was reported in 24 S. maltophilia pulsotypes of isolates depending on their genetic characteristics [35]. Bacillus subtilis is an established model system to investigate the molecular mechanisms of biofilm formation and development. Bacilus subtilis growth kinetics and morphological features were characterized for colony type biofilm formation previously [64]. The complexity of B. subtillis biofilm is characterized by a rapidly developing three-dimensional complex structure with the core size remains largely unchanged while the colony expansion is mostly attributed to the growth in the area of outer cell subpopulations [65]. Oliveira et al. [66] indicated that CAEOs were effective in controlling multi-species biofilms. 
Kačániová et al. [67] evaluated the effect of coriander oil on S. maltophillia and B. subtilis plankton and biofilm cells with a similar MALDI-TOF MS staining method on biofilm development. The authors found that this method was effective in distinguishing the changes in the spectra of bacterial biofilm development under specific conditions. Coriander essential oil expressed the antibacterial activity against B. subtilis, S. maltophilia and Penicillium expansum. The strongest antimicrobial activity was found against $B$. subtilis, while the strongest antibiofilm activity was detected against $S$. maltophilia.

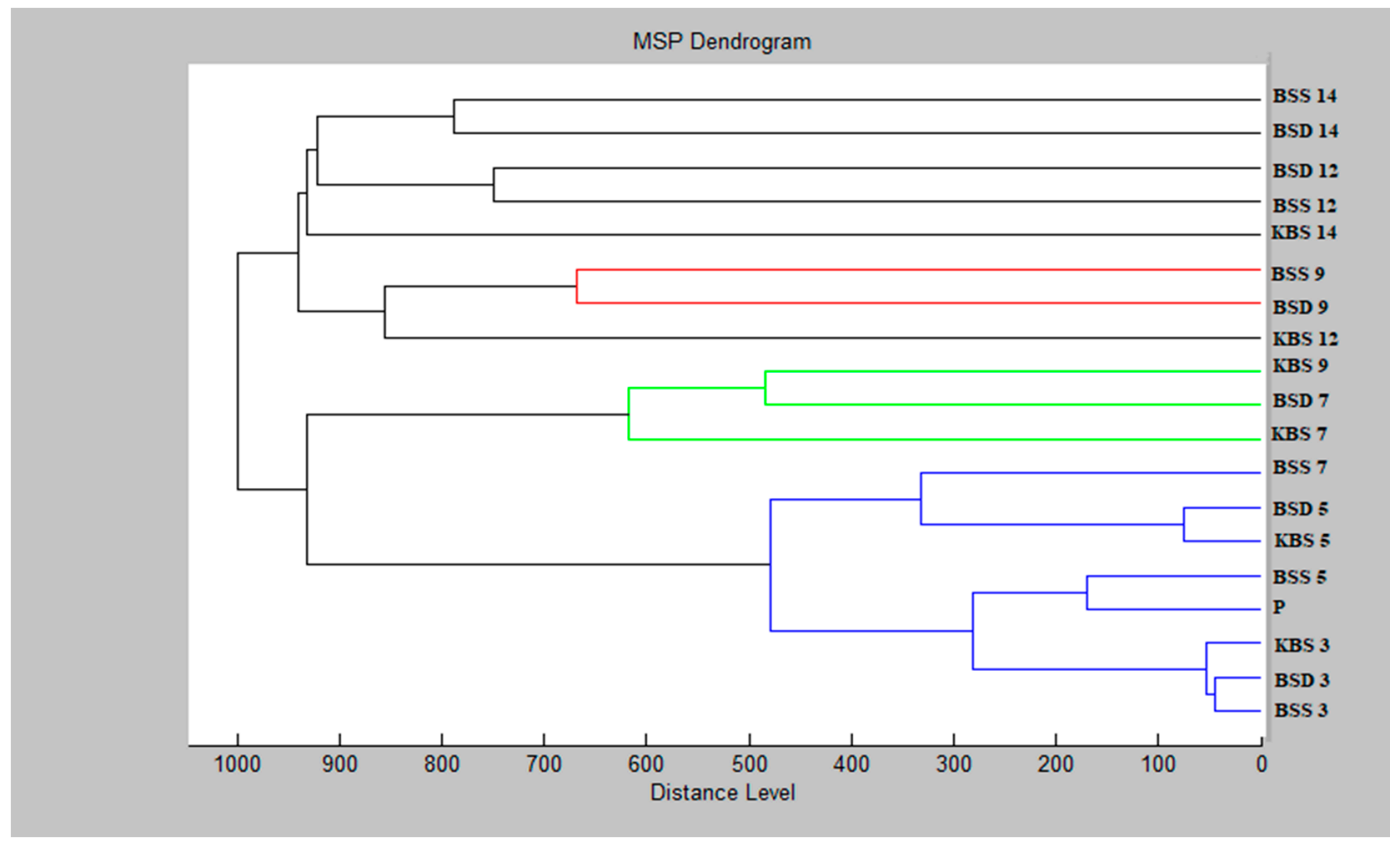

Figure 4. Dendrogram of $B$. subtilis with MSPs for planktonic cells and control. The sample names are abbreviated as follows: B, B. subtilis; K, control; S, glass; D, wood; P, planktonic cells.

\subsection{Water Activity and Moisture Content}

The moisture content of bread was $41.467 \pm 0.881 \%$, and water activity was $0.945 \pm 0.002$. After baking, the bread quality depends on $\mathrm{a}_{\mathrm{w}}$ and moisture content; these parameters are known to directly affect the shelf life of the product [68]. Bread $a_{w}$ indicates the water availability for microbial growth and represents a substantial impact on the growth of microorganisms in foods [69,70], and $a_{w}$ below 0.7 shows a preventive effect on the microbial spoilage [71]. The value for $\mathrm{a}_{\mathrm{w}}$ in white bread within the range of 0.94 to 0.97 [72] indicates that the bread is susceptible to microbial spoilage, mainly attributed to the growth of various molds.

According to Lahlali et al. [73], bread is a food product with intermediate moisture, typically ranging from $35-42 \%$ [74], which corresponds to our results. The moisture content of $42 \%$ and $41.89 \%$ for white bread reported by Lee et al. [75] and Jaekel et al. [76] corresponds to our findings.

The most common fungi found in bakery products include Rhizopus, Aspergillus, Penicillium, Monilia, Mucor, and Eurotium [77]. Penicillium expansum is more resistant to harsh environmental conditions in comparison with other representatives of Penicillium species; therefore, this fungus was used as a model in our study [78]. 


\subsection{In Situ Antifungal Analysis on Bread}

Minimum inhibitory doses ( $\mathrm{MID}_{50}$ and $\mathrm{MID}_{90}$ ) of CAEO against Penicillium crustosum on bread after 14 days were 98.71 and 123.39 (Figure 5), 136.52 and 188.40 against $P$. citrinum and 353.12 and 564.99 against P. expansum, respectively. Previously reported $\mathrm{MID}_{50}$ and $\mathrm{MID}_{90}$ for coriander EOs for growth inhibition of Penicillium expansum on bread after 14 days were 367.19 and 445.92, respectively [67] The CAEO can be applied in the production and processing of different foods of plant and animal origin based materials, e.g., meat, fish, cheese, and cosmetic industry, for the production of different hygienic products and fragrances. Multilateral physiological effects are well-known and widely utilized in medicine [57].

Fusarium oxysporum, F. solani, F. avenaceum, Botrytis cinerea, and Bipolaris sorokiniana were treated with the CAEO, and the activity of CAEO was variable depending on the applied dose of the essential oil and the fungal species [79].

\subsection{In Situ Antimicrobial Effect on Carrot}

The antimicrobial study of CAEO was determined in an in situ study. A better antibacterial activity of CAEO was found against $B$. subtilis with a concentration of 62.5 (Figure 6E). Previously reported antimicrobial activity of CAEO against $B$. subtilis ranged from 5 to $10 \mathrm{mg} / \mathrm{mL}$ [80]. The antimicrobial activity against $S$. maltophilia was demonstrated by cinnamon, thyme, and clove essential oils [81].

The best antifungal activity of CAEO was found against $P$. crustosum (Figure 6A-D). The growth of $P$. chrysogenum was inhibited by the application of citrus plants essential oils, grapefruit essential oil being the most active. Antimicrobial effects of essential oils of sweet orange [82,83] and pummelo [84] against $P$. chrysogenum and $P$. expansum were described as highly effective. Furthermore, the antifungal activity of CAEOs has been described against Penicillium spp. and P. verrucosum [85].

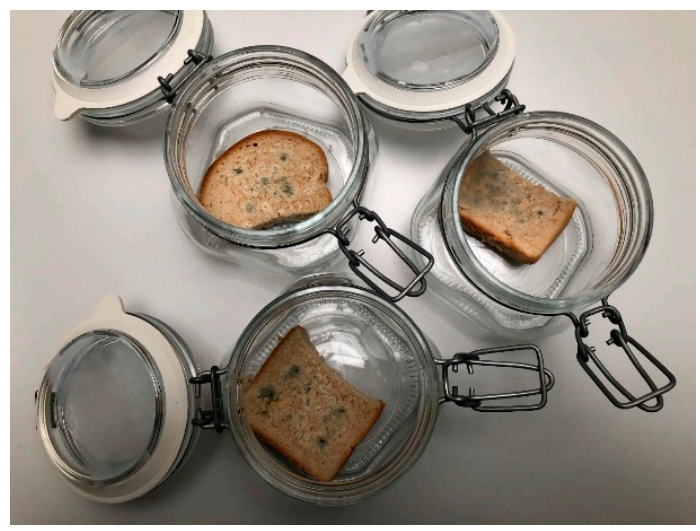

Figure 5. In situ antifungal analysis of bread inoculated with Penicillium crustosum in vapor phase. 

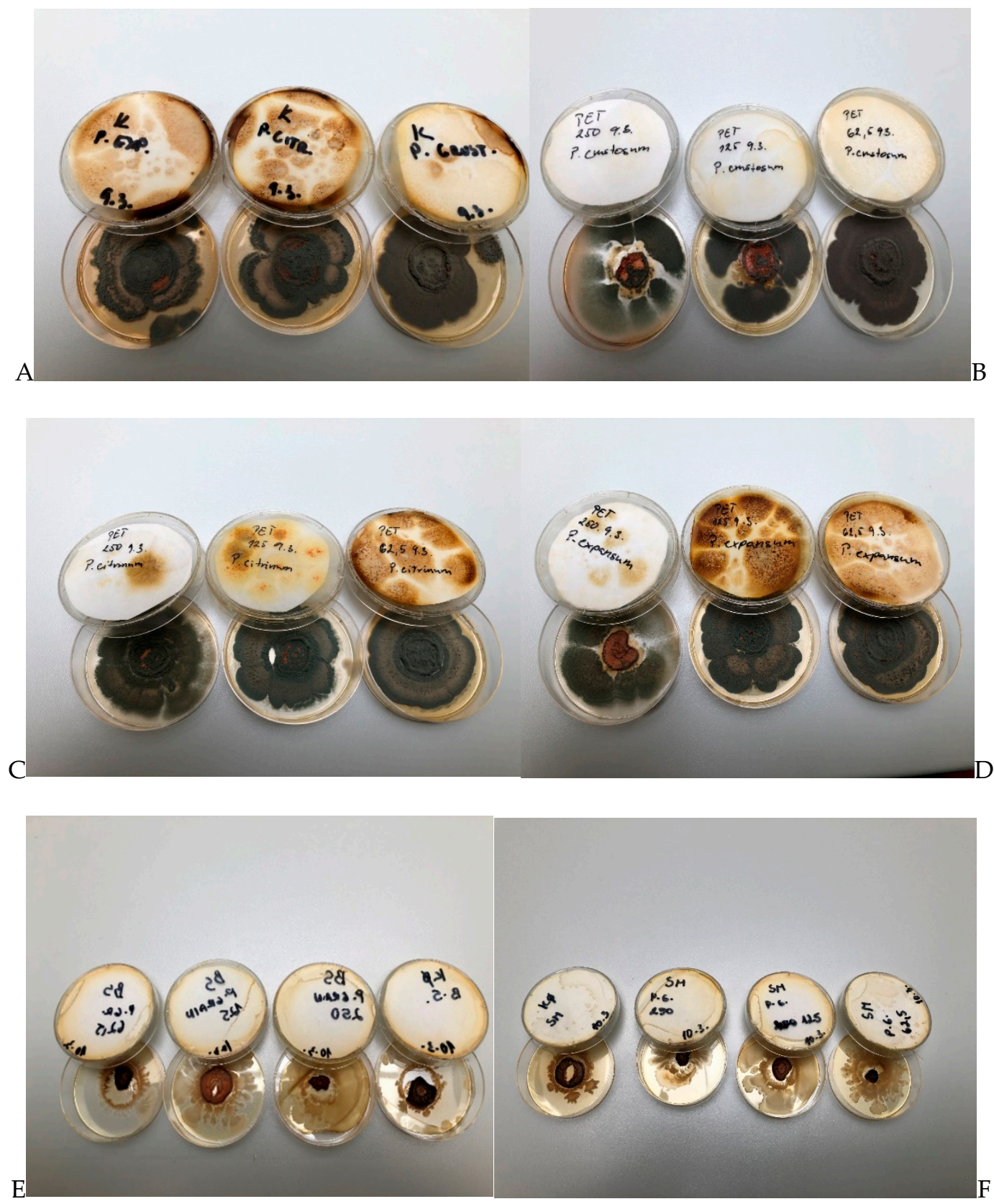

Figure 6. In situ antimicrobial analyses of carrot with Penicillum spp. in vapor phase ((A) control with fungi, (B) P. crustosum, (C) P. citrinum, (D) P. expansum, (E) B. subtillis, (F) S. maltiphilia).

\section{Materials and Methods}

\subsection{Essential Oil}

The tested essential oil (Citrus aurantium, CAEO, bitter orange) was purchased from the company Hanus, a.s. located in Nitra, Slovakia. The chemical analysis of the CAEO was done prior to the detection of the biological activity.

\subsection{Chemical Composition of Essential Oil}

Gas chromatographic-mass spectrometric analysis of the essential oil was performed as in a previous work of Kačániová et al. [67]. The results are expressed as mean values of three injections \pm standard errors (SE). 


\subsection{Radical Scavenging Activity-DPPH Method}

The radical scavenging activity of the essential oil was determined using the 2,2-diphenyl-1-picrylhydrazyl (DPPH) assay, according to Sánchés-Moreno et al. [86] with small modifications [64].

\subsection{Microorganisms}

The bacterial species of Stenotrophomonas maltophilia and Bacillus subtilis were obtained from the milk industry and identified with the MALDI-TOF MS Biotype and 16S rRNA sequencing. The bacteria strains were tested for the antimicrobial resistance, antimicrobial, antioxidant, and antibiofilm activity. The fungi Penicillium expansum, P. crustosum, and P. citrinum were isolated from grape samples and identified with the MALDI-TOF MS Biotyper and 16S rRNA sequencing.

\subsection{Antimicrobial Activity}

The antibacterial activity was examined by the agar disc diffusion method. S. maltophilia and B. subtilis were incubated in Mueller Hinton broth (MHB, Oxoid, Basingstoke, UK) at $37^{\circ} \mathrm{C}$ for $24 \mathrm{~h}$. P. expansum, P. crustosum, and P. citrinum were incubated in Sabouraud broth (SB, Oxoid, Basingstoke, UK) at $25{ }^{\circ} \mathrm{C}$ for $48 \mathrm{~h}$. The isolates were identified by useof the MALDI-TOF MS Biotyper (Bruker Daltonic, Bremen, Germany) with a score higher than 2.2. Microbial suspensions were prepared in saline and adjusted to $0.5 \mathrm{McF}$ arland turbidity standards with a densilameter (Erba Lachema s.r.o., Brno, Czech Republic). The isolates were used for inoculation onto the Mueller-Hinton agar (MHA) and Sabouraud agars, subsequently discs impregnated by the tested EOs $(10 \mu \mathrm{L} / \mathrm{disc})$ were used for the detection of the antimicrobial activity. MHA were incubated at $4{ }^{\circ} \mathrm{C}$ for $1-2 \mathrm{~h}$, and then at $37^{\circ} \mathrm{C}$ and $25^{\circ} \mathrm{C}$ for $18-24 \mathrm{~h}$ and $48 \mathrm{~h}$ for bacteria and microscopic fungi, respectively. The antimicrobial activity was evaluated by measuring the zone of growth inhibition around the discs following incubation. Chloramphenicol (30 $\mu \mathrm{g}$, Oxoid, Basingstoke, UK) and fluconazole ( $25 \mu \mathrm{g}$, Oxoid, Basingstoke, UK) served as positive antimicrobial controls.

\subsection{Minimum Biofilm Inhibitory Concentration (MBIC)}

MBIC analysis was done on a microtitration plate. Taking advantage of the agar microdilution method, we determined the anti-biofilm activity of the CAEO for S. maltophilia [87]. The bacterial culture was cultivated on $\mathrm{MHB}$ at $37^{\circ} \mathrm{C}$ for $24 \mathrm{~h}$. After cultivation, bacterial suspension with a density of $10^{8} \mathrm{CFU} / \mathrm{mL}$ was prepared. One hundred $\mu \mathrm{L}$ of the bacterial suspension was transferred into a 96-well microtitration plate, subsequently, $100 \mu \mathrm{L}$ of the essential oil at a concentration from $0.3125 \mu \mathrm{L}$ to $10 \mu \mathrm{L}$ per well were added. MHB with the essential oil was used as a negative control. As a control of the maximum growth, MHBs inoculated with microorganisms were used. The microplates were incubated at $37^{\circ} \mathrm{C}$ for $24 \mathrm{~h}$, and then the supernatant was poured away. The wells were washed 3 times with $250 \mu \mathrm{l}$ of saline solution and dried for $30 \mathrm{~min}$. Crystal violet $(200 \mu \mathrm{L}$ of $0.1 \%(w / v))$ was subsequently added to each well of the dried microplate and allowed to stain for $15 \mathrm{~min}$ with a repeated wash. The samples were resolubilized with $200 \mu \mathrm{L} \mathrm{33 \%}$ acetic acid [88]. The absorbance was measured with a spectrophotometer (Promega Inc., Madison, WI, USA) at $570 \mathrm{~nm}$. The concentration of the essential oil at which the absorbance was less than or equal to the negative control was determined as MBIC. The test was performed in triplicate.

\subsection{Biofilm Development and Molecular Differences on Different Surfaces with MALDI-TOF MS Biotyper}

S. maltophilia and B. subtilis cultures were pre-inoculated in MHB at $37^{\circ} \mathrm{C}$ for $24 \mathrm{~h}$. Ten $\mu \mathrm{L}$ of each inoculum was added to $20 \mu \mathrm{L}$ of MHB in $50 \mu \mathrm{L}$ polypropylene tubes that contained a glass slide, and a wooden toothpick. $0.1 \%$ CAEO was added to the bacterial cultures. The prepared samples were incubated on a shaker at $170 \mathrm{rpm}$ and $37^{\circ} \mathrm{C}$ with a $45^{\circ}$ inclination. Experimental samples of the biofilm and control specimens of planktonic cells were taken after $3,5,7,9,12$, and 14 days. 
Biofilm samples were wiped by a sterile cotton swab from a glass slide or wooden toothpick and subsequently applied in duplicate directly on a polished 96-well MALDI-TOF MS Biotyper plate (Bruker Daltonics, Bremen, Germany). Planktonic cells were obtained from planktonic cell suspension and centrifuged at $3000 \times g$ for $3 \mathrm{~min}$. The pellet was used for the analysis with MALDI-TOF MicroFlex (Bruker Daltonics, Germany). A linear and positive mode for the range of $\mathrm{m} / \mathrm{z} 200-2000$ was used.

The standard global spectrum (MSP) of the samples was represented by 40 mass spectra generated for every sample by the MALDI Biotyper 3.0 software (Bruker Daltonics, Germany), the spectra were obtained automatically and analyzed with the MALDI Biotyper dendrogram method using Euclidean distances [63]. The measured spectra were compared to FlexAnalysis 3.0 (Bruker Daltonics, Germany).

\subsection{Bread Making Process}

The baking formula consisted of wheat flour T650 (250 g), water $(150 \mathrm{~mL})$, saccharose $(2.5 \mathrm{~g})$, salt ( $5 \mathrm{~g})$, and yeast ( $5 \mathrm{~g})$. All the ingredients were mixed in a spiralmixer (Diosna SP $12 \mathrm{D}$; Diosna; Germany) for $6 \mathrm{~min}$. The prepared dough was placed into an aluminum vessel and transferred to a fermentation cabinet (MIWE cube; Pekass s.r.o., Plzeň, Czech Republic) at $32{ }^{\circ} \mathrm{C}$ and $85 \%$ relative humidity for $40 \mathrm{~min}$. The loaves were baked in two stages: (i) At $180{ }^{\circ} \mathrm{C}$ for $17 \mathrm{~min}$ with the addition of $160 \mathrm{~mL}$ water and (ii) at $210^{\circ} \mathrm{C}$ for $10 \mathrm{~min}$ in a steamy oven (MIWE cube). Following baking, the bread was left to stand at laboratory temperature for $2 \mathrm{~h}$, and then analyzed.

\subsection{Water Activity and Moisture Content}

Cooled breadcrumbs water activity $\left(\mathrm{a}_{\mathrm{w}}\right)$ was measured with a Lab Master aw Standard (Novasina AG; Lachen, Switzerland) at $25 \pm 0.3^{\circ} \mathrm{C}$. The moisture content was determined by the Kern DBS 60-3 moisture analyzer (Kern and Sohn $\mathrm{GmbH}$, Balingen, Germany) at $120^{\circ} \mathrm{C}$.

\subsection{In Situ Antifungal Analysis on Bread}

The bread samples were cut into slices with a height of $150 \mathrm{~mm}$ and placed into $0.5 \mathrm{~L}$ sterile glass jars (Bormioli Rocco, Fidenza, Italy). A fungal spore suspension of each strain (final concentration of $1 \times 10^{6}$ spores $/ \mathrm{mL}$ ) was diluted in $20 \mathrm{~mL}$ of sterile phosphate-buffered saline with $0.5 \%$ Tween 80 by adjusting the density to 1-1.2 McFarland and $5 \mu \mathrm{L}$ of inoculum was used for bread inoculation. CAEO concentrations of 125, 250, and $500 \mu \mathrm{L} / \mathrm{L}$ (EOs + ethyl acetate) were evenly distributed on a sterile paper-filter disc $(6 \mathrm{~cm})$, which was inserted into the cover of the jar, except for the treatment of the control group. The jars were hermetically closed and kept at $25^{\circ} \mathrm{C} \pm 1{ }^{\circ} \mathrm{C}$ for 14 days in the dark. The colonies with visible mycelial growth and visible sporulation were evaluated [66].

\subsection{Vapor Phase of Antimicrobial Assay with Carrot}

Carrot samples were cut into slices of $5 \mathrm{~mm}$. Warm PDA (potato dextrose agar; Oxoid, Basingstoke, UK) was poured into $60 \mathrm{~mm}$ Petri dishes (PD) and the lid, and $5 \mu \mathrm{L}$ of inoculum prepared as described in chapter 2.10 were applied to the carrot slices. The EOs were two-fold diluted in ethyl acetate to a final volume of 250,125, and $62.5 \mu \mathrm{L}$ and transferred on a $55 \mathrm{~mm}$ round sterile filter paper using a micropipette. The filter paper was dried for $1 \mathrm{~min}$ for the evaporation of ethyl acetate and subsequently laid into the PD on the walls to ensure a $2 \mathrm{~mm}$ distance between the paper and the agar. Finally, the PD was hermetically closed with its lid containing the solidified agar. The Petri dishes were incubated at $37^{\circ} \mathrm{C}$ for $18-24 \mathrm{~h}$ and at $25^{\circ} \mathrm{C}$ for $72 \mathrm{~h}$ for bacteria and fungi, respectively.

\subsection{Statistical Analysis}

The measurements were carried out in triplicate. Statistical variability of the data was processed with Microsoft ${ }^{\mathrm{TM}}$ Excel $^{\circledR}$ program. MBIC50 and MBIC90 values (concentration causing 50\% and $90 \%$ reduction of bacterial biofilm growth) were estimated by the logit analysis. 


\section{Conclusions}

CAEO showed a satisfactory biological activity and inhibitory effects on biofilm formation. The results were confirmed by the protein spectrum analysis, cluster similarity analysis (dendrograms), and the antibiofilm activity of the essential oil. It can be assumed that the effect of CAEO is based on disrupting the polysaccharides in biofilms, thereby decreasing their resistance. MALDI-TOF MS profiling is a very convenient equipment to identify microorganisms and it is also suitable to analyze the biofilm profile.

MALDI-TOF MS Biotyper is a useful method to distinguish between different phases of the biofilm and to detect their transition to the dispersed stage. The present study highlights the possible use of MALDI-TOF technology in clinical diagnostics and prognostic processing of biofilm formation and/or control. The global concerns on antimicrobial resistance and health-related consequences facilitate a necessity to look for natural alternatives with antimicrobial properties. Our study has demonstrated the antimicrobial effect of CAEO that could be applicable for the food industry and health care needs.

Author Contributions: M.K., L.G., S.K., E.I., V.V., P.B., J.Š. were responsible for the design of the study; M.K., L.G., S.F. conducted the study and collected the samples. M.K., L.G., E.I., J.Š., P.B., V.V. performed the laboratory analysis. M.K., L.G, N.V., J.Š., V.V., P.B., J.Ž., P.Ł.K., M.T., R.B.P., E.T. were responsible for data processing, writing and editing the manuscript. All authors have read and agreed to the published version of the manuscript.

Funding: This work was supported by the grant APVV SK-BY-RD-19-0014 "The formulation of novel compositions and properties study of the polysaccharides based edible films and coatings with antimicrobial and antioxidant plant additives".

Acknowledgments: The Paper was supported by the project: The research leading to these results has received funding from the European Community under project no. 26220220180: Building Research Centre "AgroBioTech".

Conflicts of Interest: The authors declare no conflict of interest.

\section{References}

1. De Moraes Pultrini, A.; Almeida Galindo, L.; Costa, M. Effects of the essential oil from Citrus aurantium L. in experimental anxiety models in mice. Life Sci. 2006, 78, 1720-1725. [CrossRef] [PubMed]

2. Park, K.-I.; Park, H.-S.; Kim, M.-K.; Hong, G.-E.; Nagappan, A.; Lee, H.-J.; Yumnam, S.; Lee, W.-S.; Won, C.-K.; Shin, S.-C.; et al. Flavonoids identified from Korean Citrus aurantium L. inhibit Non-Small Cell Lung Cancer growth in vivo and in vitro. J. Funct. Foods 2014, 7, 287-297. [CrossRef]

3. Moraes, T.M.; Kushima, H.; Moleiro, F.C.; Santos, R.C.; Machado Rocha, L.R.; Marques, M.O.; Vilegas, W.; Hiruma-Lima, C.A. Effects of limonene and essential oil from Citrus aurantium on gastric mucosa: Role of prostaglandins and gastric mucus secretion. Chem. Biol. Interact. 2009, 180, 499-505. [CrossRef]

4. Fugh-Berman, A.; Myers, A. Citrus aurantium, an Ingredient of Dietary Supplements Marketed for Weight Loss: Current Status of Clinical and Basic Research. Exp. Biol. Med. 2004, 229, 698-704. [CrossRef] [PubMed]

5. Hansen, D.K.; George, N.I.; White, G.E.; Pellicore, L.S.; Abdel-Rahman, A.; Fabricant, D. Physiological effects following administration of Citrus aurantium for 28days in rats. Toxicol. Appl. Pharmacol. 2012, 261, 236-247. [CrossRef]

6. Peixoto, J.S.; Comar, J.F.; Moreira, C.T.; Soares, A.A.; de Oliveira, A.L.; Bracht, A.; Peralta, R.M. Effects of Citrus aurantium (Bitter Orange) Fruit Extracts and p-Synephrine on Metabolic Fluxes in the Rat Liver. Molecules 2012, 17, 5854-5869. [CrossRef]

7. Kang, S.R.; Park, K.I.; Park, H.S.; Lee, D.H.; Kim, J.A.; Nagappan, A.; Kim, E.H.; Lee, W.S.; Shin, S.C.; Park, M.K.; et al. Anti-inflammatory effect of flavonoids isolated from Korea Citrus aurantium L. on lipopolysaccharide-induced mouse macrophage RAW 264.7 cells by blocking of nuclear factor-kappa B (NF-кB) and mitogen-activated protein kinase (MAPK) signalling pathways. Food Chem. 2011, 129, 1721-1728. [CrossRef]

8. Hamada, Y.; Nakajima, M.; Tsuzuki, K.; Amakura, Y.; Yoshimura, M.; Okuyama, S.; Furukawa, Y. Heptamethoxyflavone Reduces Phosphodiesterase Activity and T-Cell Growth in vitro. Int. Arch. Allergy Immunol. 2017, 174, 113-120. [CrossRef] 
9. Liu, L.; Shan, S.; Zhang, K.; Ning, Z.-Q.; Lu, X.-P.; Cheng, Y.-Y. Naringenin and hesperetin, two flavonoids derived from Citrus aurantium up-regulate transcription of adiponectin. Phyther. Res. 2008, 22, 1400-1403. [CrossRef]

10. Zhang, X.-L.; Xu, W.-F.; Chen, G.; Wang, H.-F.; Pei, Y.-H. Two new phenolic glycosides isolated from the fruits of Citrus aurantium. Chin. J. Nat. Med. 2017, 15, 41-44. [CrossRef]

11. Pellati, F.; Benvenuti, S.; Melegari, M. High-performance liquid chromatography methods for the analysis of adrenergic amines and flavanones in Citrus aurantium L. var.amara. Phytochem. Anal. 2004, 15, 220-225. [CrossRef] [PubMed]

12. Bagatela, B.S.; Lopes, A.P.; Cabral, E.C.; Perazzo, F.F.; Ifa, D.R. High-performance thin-layer chromatography/desorption electrospray ionization mass spectrometry imaging of the crude extract from the peels of Citrus aurantium L. (Rutaceae). Rapid Commun. Mass Spectrom. 2015, 29, 1530-1534. [CrossRef] [PubMed]

13. Kang, P.; Ryu, K.-H.; Lee, J.-M.; Kim, H.-K.; Seol, G.H. Endothelium- and smooth muscle-dependent vasodilator effects of Citrus aurantium L. var. amara: Focus on Ca2+ modulation. Biomed. Pharmacother. 2016, 82,467-471. [CrossRef] [PubMed]

14. Kostopoulou, Z.; Therios, I.; Roumeliotis, E.; Kanellis, A.K.; Molassiotis, A. Melatonin combined with ascorbic acid provides salt adaptation in Citrus aurantium L. seedlings. Plant. Physiol. Biochem. 2015, 86, 155-165. [CrossRef]

15. Pellati, F.; Benvenuti, S. Erratum to "Chromatographic and electrophoretic methods for the analysis of phenethylamine alkaloids in Citrus aurantium" [J. Chromatogr. A 1161 (2007) 71-88]. J. Chromatogr. A 2007, 1164, 334. [CrossRef]

16. Kamal, G.M.; Anwar, F.; Hussain, A.I.; Sarri, N.; Ashraf, M.Y. Yield and chemical composition of Citrus essential oils as affected by drying pretreatment of peels. Int. Food Res. J. 2011, 18, 1275.

17. Nunes Wolffenbuttel, A.; Zamboni, A.; Kerpel dos Santos, M.; Tassi Borille, B.; Americo Augustin, O.; de Cassia Mariotti, K.; Bainy Leal, M.; Pereira Limberger, R. Chemical Components of Citrus Essential Oils from Brazil. Nat. Prod. J. 2015, 5, 14-27. [CrossRef]

18. Amorim, J.L.; Simas, D.L.R.; Pinheiro, M.M.G.; Moreno, D.S.A.; Alviano, C.S.; da Silva, A.J.R.; Dias Fernandes, P. Anti-Inflammatory Properties and Chemical Characterization of the Essential Oils of Four Citrus Species. PLoS ONE 2016, 11, e0153643. [CrossRef]

19. Ouedrhiri, W.; Bouhdid, S.; Balouiri, M.; Lalami, A.E.O.; Moja, S.; Chahdi, F.O.; Greche, H. Chemical composition of Citrus aurantium L. leaves and zest essential oils, their antioxidant, antibacterial single and combined effects. J. Chem. Pharm. Res. 2015, 7, 78-84.

20. Khakpour, S.; Khosravi, M.; Mashayekhipour, Z.; Jahromy, M.H. Effect of Citrus aurantium L. Essential Oil and Haloperidol on Anxiety in Male Mice. World J. Neurosci. 2014, 04, 427-433. [CrossRef]

21. Azhdarzadeh, F.; Hojjati, M. Chemical composition and antimicrobial activity of leaf, ripe and unripe peel of bitter orange (Citrus aurantium) essential oils. Nutr. Food Sci. Res. 2016, 3, 43-50. [CrossRef]

22. Radan, M.; Parčina, A.; Burčul, F. Chemical Composition and Antioxidant Activity of Essential Oil Obtained from Bitter Orange Peel (Citrus aurantium L.) Using Two Methods. Croat. Chem. Acta 2018, 91. [CrossRef]

23. Trabelsi, D.; Ammar, A.H.; Bouabdallah, F.; Zagrouba, F. Antioxidant and Antimicrobial Activities of Essential Oils and Methanolic Extracts of Tunisian Citrus aurantium L. IOSR J. Environ. Sci. Toxicol. Food Technol. 2014, 8, 18-27. [CrossRef]

24. Periyanayagam, K.; Dhanalakshmi, S.; Karthikeyan, V.; Magesh, M. Antibacterial activity of Citrus aurantium leaf essential oil against S. aureus and MRSA. J. Drug Discov. Ther. 2014, 2, 54-60.

25. Abderrezak, M.K.; Abaza, I.; Aburjai, T.; Kabouche, A.; Kabouche, Z. Comparative compositions of essential oils of Citrus aurantium growing in different soils. J. Mater. Environ. Sci. 2014, 5, 1913-1918.

26. Djenane, D. Chemical Profile, Antibacterial and Antioxidant Activity of Algerian Citrus Essential Oils and Their Application in Sardina pilchardus. Foods 2015, 4, 208-228. [CrossRef]

27. Leja, K.; Szudera-Kończal, K.; Świtała, E.; Juzwa, W.; Kowalczewski, P.Ł.; Czaczyk, K. The Influence of Selected Plant Essential Oils on Morphological and Physiological Characteristics in Pseudomonas Orientalis. Foods 2019, 8, 277. [CrossRef]

28. Jaglic, Z.; Desvaux, M.; Weiss, A.; Nesse, L.L.; Meyer, R.L.; Demnerova, K.; Schmidt, H.; Giaouris, E.; Sipailiene, A.; Teixeira, P.; et al. Surface adhesins and exopolymers of selected foodborne pathogens. Microbiology 2014, 160, 2561-2582. [CrossRef] 
29. Crossman, L.C.; Gould, V.C.; Dow, J.M.; Vernikos, G.S.; Okazaki, A.; Sebaihia, M.; Saunders, D.; Arrowsmith, C.; Carver, T.; Peters, N.; et al. The complete genome, comparative and functional analysis of Stenotrophomonas maltophilia reveals an organism heavily shielded by drug resistance determinants. Genome Biol. 2008, 9, R74. [CrossRef]

30. Brooke, J.S. Stenotrophomonas maltophilia: An. Emerging Global Opportunistic Pathogen. Clin. Microbiol. Rev. 2012, 25, 2-41. [CrossRef]

31. Goss, C.H.; Otto, K.; Aitken, M.L.; Rubenfeld, G.D. Detecting Stenotrophomonas maltophilia Does Not Reduce Survival of Patients with Cystic Fibrosis. Am. J. Respir. Crit. Care Med. 2002, 166, 356-361. [CrossRef] [PubMed]

32. Karpati, F.; Malmborg, A.-S.; Alfredsson, H.; Hjelte, L.; Strandvik, B. Bacterial colonisation with Xanthomonas maltophilia-a retrospective study in a cystic fibrosis patient population. Infection 1994, 22, 258-263. [CrossRef] [PubMed]

33. De Oliveira-Garcia, D.; Dall'Agnol, M.; Rosales, M.; Azzuz, A.C.G.S.; Martinez, M.B.; Girón, J.A. Characterization of Flagella Produced by Clinical Strains of Stenotrophomonas maltophilia. Emerg. Infect. Dis. 2002, 8, 918-923. [CrossRef] [PubMed]

34. Figueirêdo, P.M.S.; Furumura, M.T.; Santos, A.M.; Sousa, A.C.T.; Kota, D.J.; Levy, C.E.; Yano, T. Cytotoxic activity of clinical Stenotrophomonas maltophilia. Lett. Appl. Microbiol. 2006, 43, 443-449. [CrossRef] [PubMed]

35. Di Bonaventura, G.; Spedicato, I.; D'Antonio, D.; Robuffo, I.; Piccolomini, R. Biofilm Formation by Stenotrophomonas maltophilia: Modulation by Quinolones, Trimethoprim-Sulfamethoxazole, and Ceftazidime. Antimicrob. Agents Chemother. 2004, 48, 151-160. [CrossRef] [PubMed]

36. Di Bonaventura, G.; Pompilio, A.; Zappacosta, R.; Petrucci, F.; Fiscarelli, E.; Rossi, C.; Piccolomini, R. Role of Excessive Inflammatory Response to Stenotrophomonas maltophilia Lung Infection in DBA/2 Mice and Implications for Cystic Fibrosis. Infect. Immun. 2010, 78, 2466-2476. [CrossRef]

37. Pompilio, A.; Piccolomini, R.; Picciani, C.; D'Antonio, D.; Savini, V.; Di Bonaventura, G. Factors associated with adherence to and biofilm formation on polystyrene by Stenotrophomonas maltophilia: The role of cell surface hydrophobicity and motility. FEMS Microbiol. Lett. 2008, 287, 41-47. [CrossRef]

38. Bais, H.P.; Fall, R.; Vivanco, J.M. Biocontrol of Bacillus subtilis against Infection of Arabidopsis Roots by Pseudomonas syringae Is Facilitated by Biofilm Formation and Surfactin Production. Plant. Physiol. 2004, 134, 307-319. [CrossRef]

39. Chen, Y.; Yan, F.; Chai, Y.; Liu, H.; Kolter, R.; Losick, R.; Guo, J. Biocontrol of tomato wilt disease by Bacillus subtilis isolates from natural environments depends on conserved genes mediating biofilm formation. Environ. Microbiol. 2013, 15, 848-864. [CrossRef]

40. Demain, A.L.; Elander, R.P. The beta-lactam antibiotics: Past, present, and future. Antonie Van Leeuwenhoek 1999, 75, 5-19. [CrossRef]

41. Chakravarti, R.; Sahai, V. Compactin-A Review. Appl. Microbiol. Biotechnol. 2004, 64, 618-624. [CrossRef] [PubMed]

42. Nicoletti, R.; Ciavatta, M.L.; Buommino, E.; Tufano, M.A. Antitumor extrolites produced by Penicillium species. Int. J. Biomed. Pharm. Sci. 2008, 2, 1-23.

43. Frisvad, J.C.; Smedsgaard, J.; Larsen, T.O.; Samson, R.A. Mycotoxins, drugs and other extrolites produced by species in Penicillium subgenus Penicillium. Stud. Mycol. 2004, 49, e41.

44. Leja, K.B.; Czaczyk, K. The industrial potential of herbs and spices? A mini review. Acta Sci. Pol. Technol. Aliment. 2016, 15, 353-368. [CrossRef]

45. Liu, Q.; Meng, X.; Li, Y.; Zhao, C.-N.; Tang, G.-Y.; Li, H.-B. Antibacterial and Antifungal Activities of Spices. Int. J. Mol. Sci. 2017, 18, 1283. [CrossRef] [PubMed]

46. Felšöciová, S.; Vukovic, N.; Jeżowski, P.; Kačániová, M. Antifungal activity of selected volatile essential oils against Penicillium sp. Open Life Sci. 2020, 15, 511-521. [CrossRef]

47. Sessou, P.; Farougou, S.; Ahounou, S.; Hounnankpo, Y.; Azokpota, P.; Youssao, I.; Sohounhlou, D. Comparative Study of Antifungal Activities of Six Selected Essential Oils against Fungal Isolates from Cheese Wagashi in Benin. Pakistan J. Biol. Sci. 2013, 16, 1751-1757. [CrossRef]

48. Gandomi, H.; Misaghi, A.; Basti, A.A.; Bokaei, S.; Khosravi, A.; Abbasifar, A.; Javan, A.J. Effect of Zataria multiflora Boiss. essential oil on growth and aflatoxin formation by Aspergillus flavus in culture media and cheese. Food Chem. Toxicol. 2009, 47, 2397-2400. [CrossRef] 
49. Bourgou, S.; Rahali, F.Z.; Ourghemmi, I.; Saïdani Tounsi, M. Changes of Peel Essential Oil Composition of Four Tunisian Citrus during Fruit Maturation. Sci. World J. 2012, 2012, 1-10. [CrossRef]

50. Rahimi, A.; Hashemi, P.; Talei, G.R.; Borzuei, M.; Ghiasvand, A.R. Comparative analyses of the volatile components of Citrus aurantium L. flowers using ultrasonic-assisted headspace SPME and hydrodistillation combined with GC-MS and evaluation of their antimicrobial activities. Anal. Bioanal. Chem. Res. 2014, 1, 83-91. [CrossRef]

51. Sarrou, E.; Chatzopoulou, P.; Dimassi-Theriou, K.; Therios, I. Volatile Constituents and Antioxidant Activity of Peel, Flowers and Leaf Oils of Citrus aurantium L. Growing in Greece. Molecules 2013, 18, 10639-10647. [CrossRef] [PubMed]

52. Zarrad, K.; Hamouda, A.B.; Chaieb, I.; Laarif, A.; Jemâa, J.M.-B. Chemical composition, fumigant and anti-acetylcholinesterase activity of the Tunisian Citrus aurantium L. essential oils. Ind. Crops Prod. 2015, 76, 121-127. [CrossRef]

53. Khettal, B.; Kadri, N.; Tighilet, K.; Adjebli, A.; Dahmoune, F.; Maiza-Benabdeslam, F. Phenolic compounds from Citrus leaves: Antioxidant activity and enzymatic browning inhibition. J. Complement. Integr. Med. 2017, 14. [CrossRef] [PubMed]

54. Bendaha, H.; Bouchal, B.; El Mounsi, I.; Salhi, A.; Berrabeh, M.; El Bellaoui, M.; Mimouni, M. Chemical composition, antioxidant, antibacterial and antifungal activities of peel essential oils of Citrus aurantium grown in Eastern Morocco. Der Pharm. Lett. 2016, 8, 239-245.

55. Choi, H.-S.; Song, H.S.; Ukeda, H.; Sawamura, M. Radical-Scavenging Activities of Citrus Essential Oils and Their Components: Detection Using 1,1-Diphenyl-2-picrylhydrazyl. J. Agric. Food Chem. 2000, 48, 4156-4161. [CrossRef]

56. Madhuri, S.; Hegde, A.U.; Srilakshmi, N.S.; Prashith Kekuda, T.R. Antimicrobial activity of citrus sinensis and Citrus aurantium peel extracts. J. Pharm. Sci. Innov. 2014, 3, 366-368. [CrossRef]

57. Teneva, D.; Denkova-Kostova, R.; Goranov, B.; Hristova-Ivanova, Y.; Slavchev, A.; Denkova, Z.; Kostov, G. Chemical composition, antioxidant activity and antimicrobial activity of essential oil from Citrus aurantium $\mathrm{L}$. zest against some pathogenic microorganisms. Z. Naturforsch. C 2019, 74, 105-111. [CrossRef]

58. Casquete, R.; Castro, S.M.; Martín, A.; Ruiz-Moyano, S.; Saraiva, J.A.; Córdoba, M.G.; Teixeira, P. Evaluation of the effect of high pressure on total phenolic content, antioxidant and antimicrobial activity of citrus peels. Innov. Food Sci. Emerg. Technol. 2015, 31, 37-44. [CrossRef]

59. Randazzo, W.; Jiménez-Belenguer, A.; Settanni, L.; Perdones, A.; Moschetti, M.; Palazzolo, E.; Guarrasi, V.; Vargas, M.; Germanà, M.A.; Moschetti, G. Antilisterial effect of citrus essential oils and their performance in edible film formulations. Food Control. 2016, 59, 750-758. [CrossRef]

60. Settanni, L.; Palazzolo, E.; Guarrasi, V.; Aleo, A.; Mammina, C.; Moschetti, G.; Germanà, M.A. Inhibition of foodborne pathogen bacteria by essential oils extracted from citrus fruits cultivated in Sicily. Food Control. 2012, 26, 326-330. [CrossRef]

61. Fathi, H.; Paknejad, S.; Ahanjan, M. Evaluating antimicrobial effects of different orange blossom extract (Citrus aurantium L. on microbial species in vitro. Health Biotechnol. Biopharma 2017, 1, 25-36.

62. Gniewosz, M.; Kraśniewska, K.; Kosakowska, O.; Pobiega, K.; Wolska, I. Chemical compounds and antimicrobial activity of petitgrain (Citrus aurantium L. var. amara) essential oil. Herba Pol. 2017, 63, 18-25. [CrossRef]

63. Pereira, F.D.E.S.; Bonatto, C.C.; Lopes, C.A.P.; Pereira, A.L.; Silva, L.P. Use of MALDI-TOF mass spectrometry to analyze the molecular profile of Pseudomonas aeruginosa biofilms grown on glass and plastic surfaces. Microb. Pathog. 2015, 86, 32-37. [CrossRef] [PubMed]

64. Zhuo, C.; Zhao, Q.; Xiao, S. The Impact of spgM, rpfF, rmlA Gene Distribution on Biofilm Formation in Stenotrophomonas maltophilia. PLoS ONE 2014, 9, e108409. [CrossRef] [PubMed]

65. Gingichashvili, S.; Duanis-Assaf, D.; Shemesh, M.; Featherstone, J.D.B.; Feuerstein, O.; Steinberg, D. Bacillus subtilis Biofilm Development-A Computerized Study of Morphology and Kinetics. Front. Microbiol. 2017, 8. [CrossRef] [PubMed]

66. Oliveira, S.A.C.; Zambrana, J.R.M.; Di Iorio, F.B.R.; Pereira, C.A.; Jorge, A.O.C. The antimicrobial effects of Citrus limonum and Citrus aurantium essential oils on multi-species biofilms. Braz. Oral Res. 2014, 28, 22-27. [CrossRef]

67. Kačániová, M.; Galovičová, L.; Ivanišová, E.; Vukovic, N.L.; Štefániková, J.; Valková, V.; Borotová, P.; Žiarovská, J.; Terentjeva, M.; Felšöciová, S.; et al. Antioxidant, Antimicrobial and Antibiofilm Activity of Coriander (Coriandrum sativum L.) Essential Oil for Its Application in Foods. Foods 2020, 9, 282. [CrossRef] 
68. Lombard, G.E.; Weinert, I.A.G.; Minnaar, A.; Taylor, J.R.N. Preservation of South African Steamed Bread Using Hurdle Technology. LWT-Food Sci. Technol. 2000, 33, 138-143. [CrossRef]

69. Barbosa-Cnovas, G.V.; Fontana, A.J.; Schmidt, S.J.; Labuza, T.P. Water Activity in Foods: Fundamentals and Applications; Blackwell Publishing Ltd.: Oxford, UK, 2007; ISBN 9780470376454.

70. Cazier, J.-B.; Gekas, V. Water activity and its prediction: A review. Int. J. Food Prop. 2001, 4, 35-43. [CrossRef]

71. Labuzo, T.P.; Mcnally, L.; Gallagher, D.; Hawkes, J.; Hurtado, F. Stability of intermediate moisture foods. 1. Lipid oxidation. J. Food Sci. 1972, 37, 154-159. [CrossRef]

72. Roos, Y.H.; Finley, J.W.; DeMan, J.M. Water. In Principles of Food Chemistry; DeMan, J.M., Finley, J., Hurst, W.J., Lee, C., Eds.; Springer International Publishing: Gaithersburg, MD, USA, 1999; p. 606.

73. Lahlali, R.; Serrhini, M.N.; Jijakli, M.H. Studying and modelling the combined effect of temperature and water activity on the growth rate of P. expansum. Int. J. Food Microbiol. 2005, 103, 315-322. [CrossRef] [PubMed]

74. Day, L. Cereal Food Production with Low Salt. In Encyclopedia of Food Grains; Elsevier: Amsterdam, The Nederlands, 2016; pp. 396-402.

75. Lee, M.-R.; Swanson, B.G.; Baik, B.-K. Influence of Amylose Content on Properties of Wheat Starch and Breadmaking Quality of Starch and Gluten Blends. Cereal Chem. J. 2001, 78, 701-706. [CrossRef]

76. Jaekel, L.Z.; daSilva, C.B.; Steel, C.J.; Chang, Y.K. Influence of xylanase addition on the characteristics of loaf bread prepared with white flour or whole grain wheat flour. Food Sci. Technol. 2012, 32, 844-849. [CrossRef]

77. Saranraj, P.; Geetha, M. Microbial spoilage of bakery products and its control by preservatives. Int. J. Pharm. Biol. Arch. 2012, 3, 38-48.

78. Quaglia, M.; Ederli, L.; Pasqualini, S.; Zazzerini, A. Biological control agents and chemical inducers of resistance for postharvest control of Penicillium expansum Link. on apple fruit. Postharvest Biol. Technol. 2011, 59, 307-315. [CrossRef]

79. Metoui, N.; Gargouri, S.; Amri, I.; Fezzani, T.; Jamoussi, B.; Hamrouni, L. Activity antifungal of the essential oils; aqueous and ethanol extracts from Citrus aurantium L. Nat. Prod. Res. 2015, 29, 2238-2241. [CrossRef]

80. Ellouze, I.; Abderrabba, M.; Sabaou, N.; Mathieu, F.; Lebrihi, A.; Bouajila, J. Season's Variation Impact on Citrus aurantium Leaves Essential Oil: Chemical Composition and Biological Activities. J. Food Sci. 2012, 77, T173-T180. [CrossRef]

81. Fabio, A.; Cermelli, C.; Fabio, G.; Nicoletti, P.; Quaglio, P. Screening of the antibacterial effects of a variety of essential oils on microorganisms responsible for respiratory infections. Phyther. Res. 2007, 21, 374-377. [CrossRef]

82. Tao, N.; Liu, Y.; Zhang, M. Chemical composition and antimicrobial activities of essential oil from the peel of bingtang sweet orange (Citrus sinensis Osbeck). Int. J. Food Sci. Technol. 2009, 44, 1281-1285. [CrossRef]

83. Sharma, N.; Tripathi, A. Effects of Citrus sinensis (L.) Osbeck epicarp essential oil on growth and morphogenesis of Aspergillus niger (L.) Van Tieghem. Microbiol. Res. 2008, 163, 337-344. [CrossRef]

84. Van Hung, P.; Chi, P.T.L.; Phi, N.T.L. Comparison of antifungal activities of Vietnamese citrus essential oils. Nat. Prod. Res. 2013, 27, 506-508. [CrossRef] [PubMed]

85. Viuda-Martos, M.; Ruiz-Navajas, Y.; Fernández-López, J.; Pérez-Álvarez, J. Antifungal activity of lemon (Citrus lemon L.), mandarin (Citrus reticulata L.), grapefruit (Citrus paradisi L.) and orange (Citrus sinensis L.) essential oils. Food Control. 2008, 19, 1130-1138. [CrossRef]

86. Sánchez-Moreno, C.; Larrauri, J.A.; Saura-Calixto, F. A procedure to measure the antiradical efficiency of polyphenols. J. Sci. Food Agric. 1998, 76, 270-276. [CrossRef]

87. Ceri, H.; Olson, M.E.; Morck, D.W.; Storey, D.G. Minimal biofilm eradication concentration (MBEC) assay: Susceptibility testing for biofilms. Biofilms Infect. 2006, 257.

88. Hassan, A.; Usman, J.; Kaleem, F.; Omair, M.; Khalid, A.; Iqbal, M. Evaluation of different detection methods of biofilm formation in the clinical isolates. Brazilian J. Infect. Dis. 2011, 15, 305-311. [CrossRef]

Sample Availability: Samples of the compounds of CAEO and microorganisms are available from the authors. 